\title{
NOTES ON GEOGRAPHIC DISTRIBUTION
}

\section{Pisces, Syngnathidae, Hippocampus reidi : Filling distribution gaps.}

\author{
Alexandre P. Hercos ${ }^{1,2}$ \\ Tommaso Giarrizzo ${ }^{1,3}$ \\ ${ }^{1}$ Laboratório de Biologia Pesqueira e Manejo dos Recursos Aquáticos, Universidade Federal do Pará (UFPA). \\ Avenida Perimetral 2651, Terra Firme. CEP 66077-570. Belém, PA, Brazil. \\ ${ }^{2}$ Instituto de Desenvolvimento Sustentável Mamirauá (IDSM). \\ Estrada do Bexiga 2584, Fonte Boa. CEP 69470-000. Tefé, AM, Brazil. \\ ${ }^{3}$ Zentrum für Marine Tropenökologie (ZMT). \\ Fahrenheitstraße 6. 28359 Bremen, Germany.E-mail: tgiarrizzo@yahoo.it
}

The slender seahorse, Hippocampus reidi Ginsburg, 1933 is one of the most exported Brazilian marine ornamental fish species (Monteiro-Neto et al. 2003). Besides the important value in the aquarium fishes trade, $H$. reidi is collected for folk medicine, souvenirs, religious purposes (Rosa et al. 2002; Rosa et al. 2005) and it is also frequently brought up by nonselective fishing gear such as trawl nets (Foster and Vincent 2004). The high exploitation rate of slender seahorses associated with degradation of their inshore habitats (Vincent 1996) characterizes them as a threatened species (Appendix II of CITES 2004). In the states of São Paulo and Rio de Janeiro (Southeast Brazil) this species is considered a threatened species; however, population status has not been evaluated in the other states (Rosa et al. 2005).

Despite its flourishing trade and concern about its conservation status (CITES 2004; Gasparini et al. 2005) no appropriate data on biology, ecology, habitat, abundance and distribution are available for this species (Data Deficient: IUCN 2006).

Hippocampus reidi is typically found at $0.1-75 \mathrm{~m}$ depth, associated with mangrove roots, seagrass, macroalgae, oysters, cnidarians, sponges, tunicates, and artificial structures in estuaries, gorgonian coral and some on stone corals (Vari 1982; Rosa et al. 2002; Foster and Vicent 2004; Rosa et al. 2005).
The distribution of $H$. reidi extends along the western Atlantic Ocean, from North Carolina (USA) to Rio Grande do Sul (Brazil), including Gulf of Mexico and Carribean Sea (Lourie et al. 1999; Carpenter 2002). However, records from national and international museum collections available in FishBase (Froese and Pauly 2006), NEODAT II (2006) and GBIF Biodiversity Data Index, show that the geographic distribution of this species has an evident known gap of around $2.300 \mathrm{~km}$ between the northern Brazilian coast and Guyana (Figure 1A). In these coastal region only two previous unusual oceanic records of $H$. reidi (Museum of Comparative Zoology - Harvard University: FISH59348, FISH59350) are recorded at more than $250 \mathrm{~km}$ offshore. The paucity of fish fauna surveys and the high turbidity preventing SCUBA observations may explain the lack of report of $H$. reidi for this region.

Rosa et al. (2005) studying the knowledge held by Brazilian fishers on the biology and ecology of the slender seahorse, recorded through interviews that seahorses are caught in Pará State (North Brazil) as a bycatch in commercial shrimp, food-fish or lobster nets. However, so far this species was never caught in fish fauna surveys in estuaries of north Brazilian coast (Barthem 1985; MartinsJuras et al. 1987; Batista and Rego 1996; Isaac et al. 1998; Camargo and Isaac 2001; Castro 2001; Krumme et al. 2004; Barletta et al. 2005; Goch et al. 2005; Giarrizzo and Krumme 2007). 


\section{NOTES ON GEOGRAPHIC DISTRIBUTION}
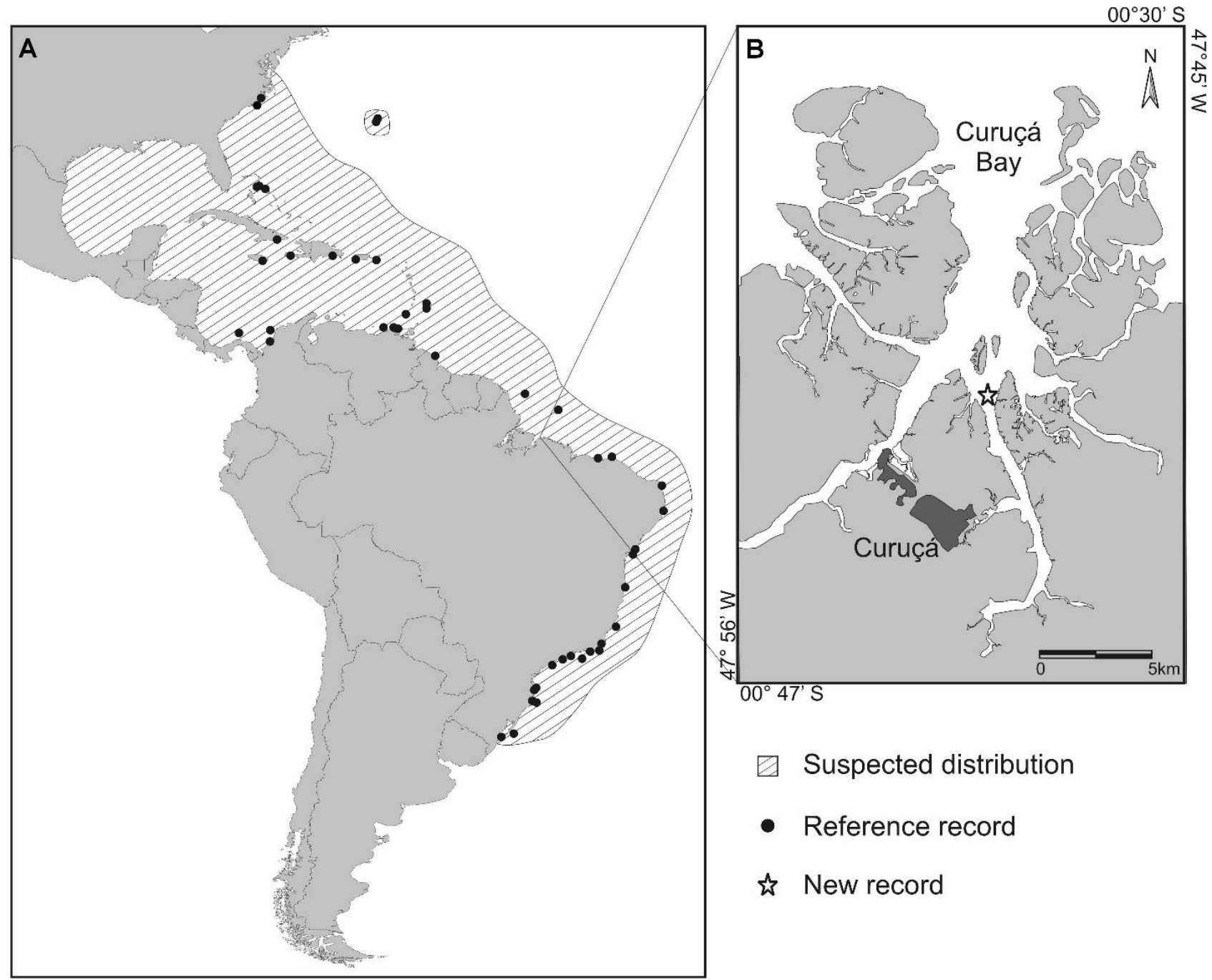

\section{Suspected distribution}

- Reference record

t) New record

Figure 1. Geographical distribution of slender seahorse, Hippocampus reidi.

This paper reports the first record of $H$. reidi from an Amazonian estuary. The fish (Figure 2) was captured in the main channel of estuary of Curuçá River (040'24" S, 47050'52" W) (Figure 1B), Pará, North Brazil, located at the eastern tip of the mouth of the southern channel of the Amazon delta (Marajó Bay). The specimen was caught on 08 July 2004, at ebb tide (around 17:00 h) using an otter trawl $(8.62 \mathrm{~m}$ width and $13 \mathrm{~mm}$ stretched mesh size) at $4 \mathrm{~m}$ depth at low tide on a muddy bottom. The environmental parameters recorded at the moment of sampling event were: $\mathrm{pH}$ 7.7, dissolved oxygen concentration $6.74 \mathrm{mg} / \mathrm{l}$, conductivity $35.0 \mu \mathrm{S} / \mathrm{cm}$, water temperature 27.8 ${ }^{\circ} \mathrm{C}$; salinity 22.1 and seston $34.87 \mathrm{mg} / \mathrm{l}$.
The specimen was preserved in alcohol and deposited in the Ichthyological Collection of the Museu Paraense Emilio Goeldi (Belém, Pará, Brazil), under the access number MPEG 11244. Identification followed Figueiredo and Menezes (1980) and Carpenter (2002). All measurements used in this paper (Table 1) were taken to the nearest $0.01 \mathrm{~mm}$ as in Lourie et al. (1999) for seahorses preserved specimens. To get around the difficulty of measuring the curvature of the trunk and tail of the seahorse, the software Scion Image Beta 4.02 (www.scioncorp.com) was used to capture, display and measure the morphometric data via a graphical interface. 


\section{NOTES ON GEOGRAPHIC DISTRIBUTION}

The fish was a female with a total body mass of $5.1 \mathrm{~g}$. Diagnostic features of the specimen are: 11 trunk rings, 33 tail rings, 3 rings supporting dorsal fin (2 trunk rings and 1 tail ring). Dorsal and pectoral fin with 17 and 16 rays, respectively. In the fresh fish the body was profusely spotted with brown dots and numerous tiny white dots.

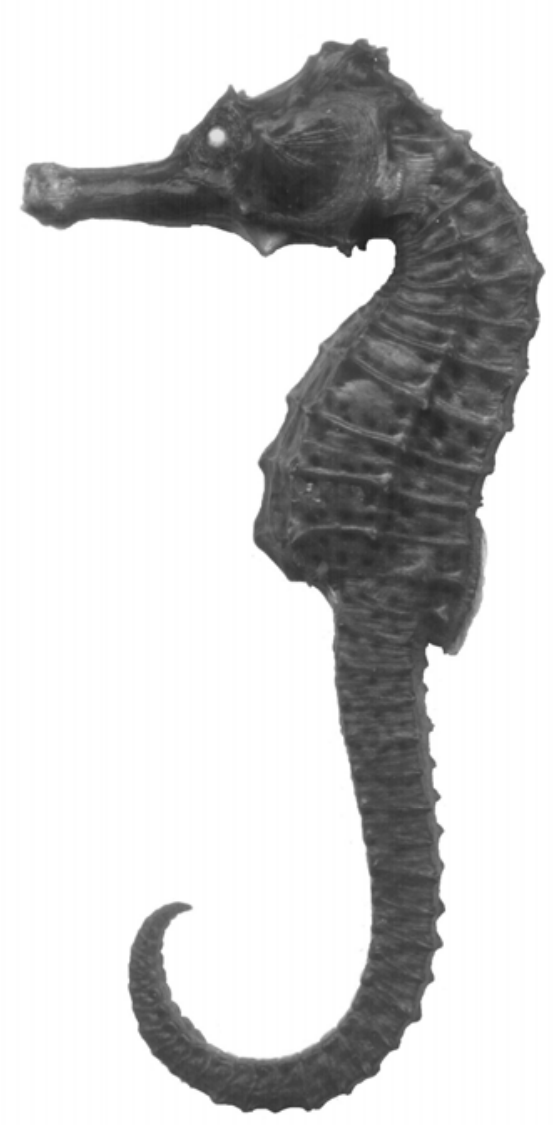

Figure 2. Hippocampus reidi (MPEG 11244) captured in the mangrove estuary of Curuçá River, Pará, North Brazil.
Table 1. Measurements of sixteen morphometric characters of Hippocampus reidi from the Curuçá estuary, Pará, Northeast Brazil.

\begin{tabular}{|c|c|}
\hline Characters & $\mathrm{mm}$ \\
\hline Standard length & 123.2 \\
\hline Trunk length & 34.37 \\
\hline Tail length & 62.42 \\
\hline Coronet height & 6.7 \\
\hline Head length & 26.41 \\
\hline Snout length & 11.72 \\
\hline Snout depth & 3.43 \\
\hline Orbital diameter & 3.98 \\
\hline Post-orbital length & 10.31 \\
\hline Head depth & 11.8 \\
\hline $\begin{array}{l}\text { Trunk depth between } 4^{\text {th }} \\
\text { and } 5^{\text {th }} \text { trunk rings }\end{array}$ & 9.12 \\
\hline $\begin{array}{l}\text { Trunk depth between } 9^{\text {th }} \\
\text { and } 10^{\text {th }} \text { trunk rings }\end{array}$ & 12.47 \\
\hline $\begin{array}{l}\text { Trunk width between } 9^{\text {th }} \\
\text { and } 10^{\text {th }} \text { trunk rings }\end{array}$ & 7.42 \\
\hline $\begin{array}{l}\text { Distance between the } 9^{\text {th }} \text { trunk } \\
\text { ring lateral ridge spine tips }\end{array}$ & 1.24 \\
\hline Pectoral fin length & 4.61 \\
\hline Dorsal fin length & 9.84 \\
\hline
\end{tabular}

\section{Acknowledgements}

We are grateful to S. Lourie for manuscript revision. This work was funded by the Millennium Initiative Project "Coastal Resources" (www.mileniodomar.org.br) financed by the Brazilian Ministry of Science and Technology. T. Giarrizzo acknowledges financial support by the CNPq grant 303958/2003-0. 


\section{NOTES ON GEOGRAPHIC DISTRIBUTION}

\section{Literature cited}

Barletta, M., A. Barletta-Bergan, and U. Saint-Paul. 2005. The role of salinity in structuring the fish assemblages in a tropical estuary. Journal of Fish Biology 66: 45-72.

Barthem, R. B. 1985. Ocorrência, distribuição e biologia dos peixes da baía de Marajó, estuário amazônico. Boletim do Museu Paraense Emílio Goeldi, Série Zoologia 2(1): 49-69.

Batista, V. S. and F. N. Rego. 1996. Análise de associações de peixes, em igarapés do estuário do rio Tibiri, Maranhão. Revista Brasileira de Biologia 56(1): 163-176.

Camargo, M. and V. J. Isaac. 2001. Os peixes estuarinos da região Norte do Brasil: Lista de espécies e considerações sobre sua distribuição geográfica. Boletim do Museu Paraense Emílio Goeldi, Série Zoologia 17(2): 133-157.

Carpenter, K. E. 2002. The living marine resources of the Western Central Atlantic. Volume 2: Bony fishes part 1 (Acipenseridae to Grammatidae). FAO species identification guide for fishery purposes and American Society of Ichthyologists and Herpetologists special publication $\mathrm{N}^{\mathrm{o}}$ 5. Roma, FAO. p. 601-1374.

Castro, A. C. L. 2001. Diversidade da assembléia de peixes em igarapés do estuário do Rio Paciência (MA - Brasil). Atlântica 23: 39-46.

CITES. 2004. Seahorses and other members of the family Syngnathidae (decision 12.54) - report of the Working Group. AC20 Doc.17. Convention on International Trade in Endangered Species of Wild Fauna and Flora (CITES), Twentieth meeting of the Animals Committee Johannesburg (South Africa). 29 March-2 April 2004

Figueiredo, J. L. and N. A. Menezes. 1980. Manual de peixes marinhos do sudeste do Brasil. III Teleostei (2). São Paulo, Museu de Zoologia Universidade de São Paulo. 90 p.

Foster, S. J. and A. C. J. Vincent. 2004. Life history and ecology of seahorses: implications for conservation and management. Journal of Fish Biology 65: 1-65.

Froese, R. and D. Pauly. 2006. FishBase. Electronic Database accessible at http://www.fishbase.org. Captured on January 2007.

Giarrizzo, T. and U. Krumme. 2007. Spatial differences and seasonal cyclicity in the intertidal fish fauna from four mangrove creeks in a salinity zone of the Curuçá Estuary, North Brazil. Bulletin of Marine Science 80: 739-754.

Gasparini, J. L., S. R. Floeter, C. E. L. Ferreira, and I. Sazima. 2005. Marine ornamental trade in Brazil. Biodiversity and Conservation 14: 2883-2899.
Goch, Y., U. Krumme, U. Saint-Paul, and J. Zuanon. 2005. Seasonal and diurnal changes in the fish fauna of a mangrove lake in the Caeté estuary, nothern Brazil. Amazoniana 18 (3/4): 299-315.

Isaac, V. J., A. R. Araújo, and J. V. Santana. 1998. A pesca no estado do Amapá: alternativas para seu desenvolvimento sustentável. Macapá, Brazil. SEMA - GEA/ BID. 132 p.

IUCN. 2006. 2006 IUCN Red list of threatened species. Accessible at http://www.iucnredlist.org. International Union for Conservation of Nature and Natural Resources, Cambridge. Captured on January 2007.

Krumme, U., U. Saint-Paul, and H. Rosenthal. 2004. Tidal and diel dynamics in a nursey area: patterns in fish migration in a mangrove in north Brazil. Aquatic Living Resources 17: 215-229.

Lourie, S. A., A. C. J. Vincent, and H. J. Hall. 1999. Seahorses: an identification guide to the world's species and their conservation. London, Project Seahorse. 204 p.

Martins-Juras, I. A. G., A. A. Juras, and N. A. Menezes. 1987. Relação preliminar dos peixes da ilha de São Luís, Maranhão, Brasil. Revista Brasileira de Biologia 4(2): 105-113.

Monteiro-Neto, C., F. E. A. Cunha, M. C. Nottingham, M. E. Araujo, I. L. Rosa, and G. M. L. Barros. 2003. Analysis of the marine ornamental fish trade at Ceará State, Northeast Brazil. Biodiversity Conservation 12 (6): 1287-1295.

Neodat II. 2006. The inter-institutional database of fish biodiversity in the Neotropics. Accessible at http://www.neodat.org. Captured on January 2007.

Rosa, I. L., T. L. Dias, and J. K. Baum. 2002. Threatened fishes of the world: Hippocampus reidi Ginsburg, 1933 (Syngnathidae). Environmental Biology of Fishes 64: 378.

Rosa, I. L., R. R. N. Alves, K. M. Bonifácio, J. S. Mourão, F. M. Osório, T. P. R. Oliveira, and M. C. Nottingham. 2005. Fishers' knowledge and seahorse conservation in Brazil. Journal of Ethnobiology and Ethnomedicine 1(12): 1-15.

Vari, R. P. 1982. Fishes of the Western North Atlantic, Part 8. Order Gasterosteiformes, Suborder Syngnathoidea. Syngnathidae (Doryrhamphinae, Syngnathinae, Hippocampinae). New Haven, Sears Foundation for Marine Research, Yale University. p. 178-193.

Vincent, A. C. J. 1996. The international trade in seahorses. Cambridge, TRAFFIC International. $163 \mathrm{p}$.

Received March 2007

Accepted September 2007

Published online October 2007 